\title{
How Does Exercise Reduce the Rate of Age-Associated Cognitive Decline? A Review of Potential Mechanisms
}

\author{
Greg Kennedy ${ }^{\mathrm{a}, *}$, Roy J. Hardman ${ }^{\mathrm{a}}$, Helen Macpherson ${ }^{\mathrm{a}, \mathrm{b}}$, Andrew B. Scholey \\ and Andrew Pipingas ${ }^{\mathrm{a}}$ \\ ${ }^{a}$ Centre for Human Psychopharmacology, Swinburne University of Technology, Melbourne, VIC, Australia \\ ${ }^{\mathrm{b}}$ Centre for Physical Activity and Nutrition Research, Deakin University, Melbourne, VIC, Australia
}

Accepted 2 August 2016

\begin{abstract}
The rate of age-associated cognitive decline varies considerably between individuals. It is important, both on a societal and individual level, to investigate factors that underlie these differences in order to identify those which might realistically slow cognitive decline. Physical activity is one such factor with substantial support in the literature. Regular exercise can positively influence cognitive ability, reduce the rate of cognitive aging, and even reduce the risk of Alzheimer's disease $(\mathrm{AD})$ and other dementias. However, while there is substantial evidence in the extant literature for the effect of exercise on cognition, the processes that mediate this relationship are less clear. This review examines cardiovascular health, production of brain derived neurotrophic factor (BDNF), insulin sensitivity, stress, and inflammation as potential pathways, via which exercise may maintain or improve cognitive functioning, and may be particularly pertinent in the context of the aging brain. A greater understanding of these mechanisms and their potential relationships with exercise and cognition will be invaluable in providing biomarkers for investigating the efficacy of differing exercise regimes on cognitive outcomes.
\end{abstract}

Keywords: BDNF, cognition, cognitive aging, exercise, inflammation, insulin, stress, vascular

\section{INTRODUCTION}

Throughout the vast majority of human history, a physically active lifestyle has been integral to our existence. However, the progressively industrialized and technological nature of modern societies has led to an ever-increasing degree of physical inactivity [1]. While reduced physical activity is endemic, across almost all countries, it is particularly prevalent in middle aged and older adults [2]. Numerous studies have found that inactivity and lower physical fitness

${ }^{*}$ Correspondence to: Greg Kennedy, Centre for Human Psychopharmacology, Swinburne University of Technology, 400 Burwood Rd, Hawthorn 3122, Australia. Tel.: +61 39214 4922; E-mail: greg.kennedy@optusnet.com.au. are associated with poorer health outcomes, such as an increase in the risk of many chronic diseases, lowered functional capacity, and reduced longevity [3-6]. Conversely, greater levels of regular exercise has been found to ameliorate these negative consequences associated with a more sedentary lifestyle $[4$, 7]. In particular, exercise appears not only to protect the brain against the structural and functional effects of aging, but also to assist in repairing or restoring the aged brain [8-10]. This neuro-protective effect translates all the way to the pathological endpoints commonly associated with cognitive decline, with regular aerobic exercise linked to a drastic reduction in the lifetime risk of clinical Alzheimer's disease (AD) and other dementias [11].

While there is considerable support in the extant literature for the beneficial effect of exercise on 
cognitive performance in both general and older population, there is a paucity of research investigating the mechanisms which may serve to mediate this relationship [12-14]. Proposed mechanisms for the observed effects of exercise on cognition include increased neurogenesis and neuroplasticity, particularly that associated with brain derived neurotrophic factor (BDNF) [15-18], improvements in cardiovascular function and the associated influence on the cerebrovascular system [19-21], reduction in stress and anxiety [22-24], reduced inflammation [25-27], and improved insulin sensitivity [28-30]. This review will first provide a brief overview of the association between exercise and cognitive decline, and then examine each of these proposed mechanisms and their relationship to cognitive aging.

\section{EXERCISE AND COGNITIVE DECLINE}

There is a substantial and ever-increasing body of evidence that exercise can promote the health and functionality of the central nervous system (CNS), reduce the cognitive decline associated with aging [31-33], and reduce the risk of cognitive impairment and dementia [34-36]. A recent systematic and meta-analytic review of 37 longitudinal studies, found that there was a negative relationship between physical activity and both dementia and cognitive decline [37]. Specifically, those with higher levels of physical activity showed less cognitive decline in comparison with those who engaged in lower levels of physical activity. Additionally, the risk of dementia was found to be $14 \%$ lower in those with higher levels of physical activity when compared to less physically active cohorts. Importantly, all but one these studies accounted for age, which is particularly important as older age is often associated with reduced regular exercise. This supports the findings of an earlier systematic review of nearly 34,000 cognitively healthy participants across 15 longitudinal studies, which found that even a low to moderate level of activity was associated with a $35 \%$ lower risk of cognitive decline when compared to the sedentary cohort [38]. A specific study by Weuve et al. [39] clearly highlighted the effect that that exercise has on cognitive aging. In this study of older women aged 71 to 80 years, regular physical activity, such as walking, was associated with reduced cognitive decline and better overall cognitive performance. Specifically, women who were in the highest quintile of overall physical activity demonstrated a mean difference in cognitive performance equivalent to being 2 to 3 years younger in age than those in the lowest quintile, while also having a $20 \%$ lower chance of global cognitive impairment [39].

Data from clinical trials is also predominantly supportive of the beneficial effect of exercise on cognition. Van Uffelen et al. [13] conducted a metaanalysis of 23 randomized controlled trials that involved older adults with healthy and/or impaired cognition. They found cognitive benefits from aerobic and strength exercise intervention for participants in one third of the studies involving cognitively healthy participants, and two thirds of studies focused on cognitively impaired participants; while no study found any negative cognitive effects associated with exercise intervention. While these findings suggest a benefit of exercise on cognition, regardless of whether participants were cognitively impaired or not [13], the authors reported that many of these studies were of poor quality and hampered by small sample sizes, limiting the ability to demonstrate significant between-group differences. A more recent meta-analysis [40] was able to address these issues, particularly via the inclusion of a number of larger, higher quality trials that had recently been completed. This review found that aerobic exercise interventions were associated with modest cognitive improvements in older people in almost all areas except, surprisingly, working memory, which tends to show a strong association with cognitive aging [41]. However, a combination of aerobic and strength training produced greater improvements than aerobic exercise alone in a number of areas including attention, processing speed, and working memory. The authors also reported preliminary evidence that exercise may, in fact, be associated with greater improvements in memory for people with mild cognitive impairment (MCI) than for cognitively healthy individuals [40]. Overall, while there is debate as to the effect size and degree of efficacy in subjects of differing cognitive statuses, these analyses broadly agree with the conclusions drawn from other reviews of controlled trials in this area [31] [42-47], that exercise interventions are associated with better cognitive outcomes in older cohorts.

\section{POTENTIAL MECHANISMS}

While it is well established that exercise generally improves cognitive health and reduces the rate of cognitive decline, very few studies have directly explored 
the specific mechanisms associated with these cognitive changes. This section represents the main body of this review, covering in turn each of the main potential mechanisms that may mediate this relationship.

\section{Cardiovascular}

It is evident that the neural and vascular systems are inextricably intertwined. The "vascular hypothesis" [48-51] proposes that vascular dysfunction, and associated risk factors, affect not only the heart but the brain as well; and that this effect on the brain has a consequential impact on cognitive functionality. It has been proposed that the risk of cognitive decline and dementia are reduced as a result of the protective influence that physical activity has on reducing vascular dysfunction and risk factors [52]. However, there is still contention as to whether cognitive decline (particularly in dementias such as AD) is a disorder of the vascular system, with consequential degeneration of the neurological system; or if neurodegeneration results in cerebral vascular dysfunction [53].

\section{Central arterial stiffness}

Increasing age is accompanied by a stiffening of the central arteries due to structural and functional changes [54]. These vessels lose their elasticity over time due to the repeated cycles of distension and elastic recoil of the arterial walls that occurs with each pulse, approximately 30 million times per year [55]. The billions of cardiac cycles over a lifetime take their toll eventually, resulting in a slow continuous process of rupture and fragmentation of the elastin fibers and deposit of more inflexible tissue such as collagen and calcium [56], causing the arteries to progressively dilate and stiffen [57, 58].

The large, elastic central cardiothoracic arteriesprincipally the aorta-buffer the pulsatile output from the heart, reducing peak pressure, and providing a continuous flow to the smaller peripheral blood vessels $[20,59,60]$. The brain and the kidneys are unique in their requirement for continual high flow perfusion throughout the cardiac cycle, and as such have lower resistance than other vascular beds [61]. This leaves the microvascular structures within these organs much more vulnerable to increases in pulsatile energy than other tissues, which are protected by more robust upstream vasoconstriction [60, 62]. A recent review of potential mechanical causes of age-related dementias [55] concluded that the destructive effects of pulse pressure, which increases with age, is likely to be a significant contributor to the development of dementia. They suggest that microbleeds occur in the small vessels of the brain because of prolonged exposure to the stress of increased pulse intensity that results from the stiffening of the larger vessels; and that the loss of neurons is a secondary result of damage to the microvasculature.

Recent systematic and meta-analytic reviews have examined the proposed three-way relationship between arterial stiffness, cerebral small vessel damage, and cognitive performance [63, 64]. Both of these reviews found a strong positive association between greater arterial stiffness and cerebral vascular disease as assessed by magnetic resonance imaging (MRI) detection of white matter hyperintensities, cerebral infarcts, lacunar infarcts, and silent brain infarcts. Both reviews also found inverse relationships between arterial stiffness and cognitive performance in cross-sectional studies, and that arterial stiffness also predicted the rate of cognitive decline in longitudinal studies. However, these cognitive relationships still require further research as they were considered statistically weak [63] and overly reliant on the Mini-Mental State Examination as the measure of cognition [64].

The degree to which progressively reduced elasticity in the central arteries can be considered "biological" as opposed to "pathological" is still a subject for debate and further investigation [57]. However regular exercise appears to be one of the best methods for reducing the rate at which such decline occurs. During exercise the heart rate is increased; however as a result of longer term exercise the heart rate remains lower at rest, thus reducing the overall number of cardiac cycles and the degree of pulsatile stress on these arteries [65]. A broad range of research has found that, in middle-aged and older people, those who engaged in regular aerobic exercise had generally lower central arterial stiffness [66-71]. Conversely, there is some evidence that resistance type training, particularly at high intensities, actually has the opposite effect and increases central arterial stiffness [72], although it is currently unclear as to whether this is a long-term detrimental effect or a necessary short-term functional/mechanical adaptation $[68,73]$. Finally, although not well researched, one recent small study has demonstrated that when compared to a sedentary cohort, middle-aged adults who regularly engaged in moderate-to- vigorous aerobic exercise not only had lower stiffness of the central arteries but also correspondingly better performance across a range of memory and attention-executive function assessments [20]. 


\section{Endothelial dysfunction}

Due to its high energy demand and relative lack of glycogen fuel reserves, the brain is highly dependent on a continuous and adequate supply of glucose from the cardiovascular system for the survival and efficient functioning of neural tissue $[74,75]$. The brain employs a number of mechanisms to ensure adequate perfusion is maintained. One mechanism, autoregulation, attempts to maintain stable cerebral perfusion despite the fluctuations in arterial pressure that occur during the cardiac cycle. In this case the cerebral arteries relax when arterial blood pressure falls and constrict when arterial pressure rises [76]. Another mechanism is the regulation of the distribution of cerebral blood flow (CBF) according to the functional requirements of different areas of the brain. This mechanism-functional hyperemia-increases blood flow to regions of the brain when activity in those areas increases. As functional hyperemia controls the delivery of substrates (such as glucose and oxygen) and the removal of the by-products of metabolism (such as carbon dioxide), it is essential for the maintenance of homeostasis in the cerebral cellular environment [74].

Endothelial reactivity, the ability of the vasculature to adjust flow in response to both internal and external stimuli, is another measure of vascular function that is distinct from central arterial stiffness. The endothelium is the layer of cells that lines the inner surface of all blood vessels. Its main purpose is to maintain adequate blood circulation, vascular tone, and the integrity of the blood vessels. These roles are achieved by the release of vasoactive compounds in response to metabolic conditions (e.g., hypercapnia or hypocapnia), chemical agonists (e.g., glutamate or acetylcholine), or the shear stress that results from a change of blood flow in the vessel $[74,77]$.

While the endothelium produces a number of vasoactive factors (for a full review, see [78]), nitric oxide (NO) is regarded as the most important endothelium-associated vasodilator. Synthesized and released by the endothelium, NO causes cerebral vasodilation, resulting in a decrease in cerebrovascular resistance and therefore an increase in CBF [79]. Reductions in NO have been associated with impaired endothelial reactivity, resulting in the impairment of autoregulation and functional hyperemia [80]. The endothelium also releases factors that reduce the accumulation and adhesion of platelets and macrophages, and the build-up of smooth muscle cells. Therefore, impaired endothelial function can result in narrowing of the arteries and a reduction of capillary density, which can chronically impede $\mathrm{CBF}$ [77], known as atherosclerosis.

The cerebral endothelium can therefore be seen as central to CBF autoregulation and functional hyperemia on both a structural and functional level. A reduction in endothelial functionality, particularly in its ability to adequately produce $\mathrm{NO}$, can result in a reduced capability to respond efficiently to changes in the blood flow demands of the brain as well as reduced overall blood flow. As with aortic stiffening, dysfunction of the vascular endothelium is regarded as a primary aspect of normal human aging and is considered the most likely underlying reason for the increased risk of cardiovascular disease associated with age [81]. Specifically, it is the capacity of the vascular endothelium to produce and react to vasodilators, particularly NO, that declines most with increasing age; thereby reducing overall $\mathrm{CBF}$ as well as the capacity of the endothelium to respond efficiently to changing conditions and demands [82]. Interestingly, general arterial function has been found to peak at around 30 years of age and then progressively decline [65], which directly parallels the age profile of cognitive decline. Additionally, even in the absence of cerebrovascular disease, recent systematic analysis concluded that impairment of the vascular endothelium was associated with poorer cognitive performance, particularly in the areas of executive control and spatial working memory [83]. There is also evidence that loss of NO causes the increased expression of the amyloid- $\beta$ precursor protein (A $\beta P P)$ as well as the $\beta$-site $A \beta P P$-cleaving enzyme 1 (BACE1), which results in the increased production of cytotoxic amyloid- $\beta$ (A $\beta)$ peptides, both in the cerebral microvessels and in the brain itself [84], a process highly associated with AD.

Regular exercise has been found to both prevent decline of, and restore function to, the vascular endothelium in middle aged and older healthy males [85]. Recent meta-analytic analysis of 51 randomized controlled trials, primarily involving middle-aged or older participants, found that aerobic and resistance exercise, both individually and in combination, significantly improved endothelial function [86]. Across these studies, higher intensity of aerobic exercise resulted in the most improvement, with a significant dose-response relationship. However, with resistance training, it was greater frequency, rather than intensity, which was associated with enhanced endothelial function [86]. These conclusions mirror those of an earlier systematic review of intervention trials [87] and are also supported by findings that 
overall cardiorespiratory fitness is positively associated with better functioning of the vascular endothelium [88]. There are a number of proposed mechanisms for this exercise resilience to age-related endothelial dysfunction, including stimulation of the endothelial cells through temporarily increased shear stress and increased localized blood flow, increased levels of circulating catecholamines during exercise and lower resting heart rate reducing mechanical stress (for review see [89] and [19]). Additionally, it has recently been proposed that exercise may also maintain or increase the number and function of endothelial progenitor cells. These bone marrow derived endothelial precursors, which decline in circulating concentration and efficacy with age, have been found in both animal and human studies, to repair endothelial damage [90].

\section{BDNF: Neural plasticity and neurogenesis}

Neurogenesis, the production of new neurons, occurs throughout life in a number of brain areas, particularly the hippocampus and cortex [91, 92], regions critically associated with memory, learning and overall cognitive performance [93-96]. Therefore, another focus of the extant literature surrounding the effects of physical activity on cognition is the capacity for exercise to promote neurogenesis and plasticity [97, 98]. Physical activity is believed to upregulate neurotrophins, a family of essential proteins that influence the development, differentiation and maintenance of neurons across the lifespan [99], and these are likely mediators of this beneficial effect of exercise on cognition [91].

Over the past 20 years there has been an accumulation of evidence, based primarily on animal investigations, that neurotrophins not only promote neuronal resilience and protect them from damage [100], but are also central mediating factors for structural and functional plasticity $[98,100,101]$. Of these neurotrophins, BDNF has emerged as a key mediator of cognition as it is highly expressed in the regions of the brain, such as the hippocampus and cortex, that exhibit the greatest degree of plasticity [99].

BDNF is the most pervasive of the neurotrophins in the developed adult brain, and affects its influence on neurons through binding with the tyrosine receptor kinase B (TrkB) receptor [102]. It is now commonly agreed that, in the adult brain, BDNF regulates structural and functional neuronal processes, in both the short and long term. Additionally, many of its effects are also regulated by neuronal activity, and it is this synergistic interplay between neurological activity and plasticity that underlie its essential role in the cognitive process [103]. BDNF has been demonstrated in numerous animal experiments to be intimately involved in memory and learning processes through the use of deletion paradigms. Focusing mainly on the hippocampus, multiple studies using BDNF and/or TrkB knockout mice have demonstrated that reduced BDNF, or BDNF binding, resulted in significant impairment of hippocampal long-term potentiation (LTP) [104-107], which results in consequential impairment of memory [108]. Conversely, introduction of exogenous BDNF facilitated LTP in BDNF-KO mice [105]. Importantly, heterozygous and homozygous BDNF-KO animal models both displayed near identical degrees of LTP impairment, indicating that a particular threshold of BDNF availability is required for effective hippocampal functioning [104].

Research has demonstrated that a brief period of exercise resulted in improved cognitive performance in terms of both learning and recalling platform location in the Morris water maze [109]. On the other hand, when the action of BDNF was blocked in the hippocampus, the cognitive performance in these animals following a period of exercise was found to be no different than sedentary controls. Additionally, animal model experimentation has consistently found that exercise, in the form of running, not only increases neurotrophin levels, but also neuronal spine density and the number of neurons produced in the hippocampus, which in turn correlates with increased spatial memory performance (for review see [110]).

Investigation of the impact of BDNF levels on humans is considerably more difficult, as fine morphological changes cannot be measured at the neuronal level [95]. However a reduction of both BDNF gene expression (mRNA) and BDNF protein is found in neurodegenerative disorders such as frontotemporal lobar degeneration, Huntington's disease, and AD [111-114]. Other human studies have examined effects of the Val66Met polymorphism, which disrupts the secretion, transport, and processing of BDNF [115]. This polymorphism has been associated with increased susceptibility for white matter hyperintensities [116, 117], reduced hippocampal volume [118-120], reduced cortical volume [118, 121], reduced hippocampal response during both the encoding and retrieval stages of memory based tasks [122], and poorer performance in cognitive tasks [120, 123]. Additionally, levels of BDNF in 
cerebrospinal fluid (CSF) have been found to decrease across the adult lifespan and lower CSF concentrations are significantly and strongly associated with reduced cognitive performance, particularly with regard to memory and, to a lesser degree, executive function [124].

BDNF can also bidirectionally cross the bloodbrain barrier (BBB) [125]. The brain contributes around $75 \%$ of circulating BDNF [126], while the remainder is produced in the peripheral nervous system as well as in other tissues such as the immune cells, lungs, heart, vascular endothelium and smooth muscle cells. Contributing significantly to serum levels, platelets contain (but do not produce) large quantities of BDNF, which has been hypothesized to play a potential role in storage for later release in times of increased requirement $[99,127]$. A recent cross-sectional study of 4,463 older people found that, while generally higher in women than men, reduced serum levels of BDNF were associated with poorer cognitive performance, once age, sex, education, and smoking status were adjusted for. Even more interestingly, levels 1.5 SD below the age- and sex-adjusted mean were associated with significantly higher risk of MCI [128].

While the brain produces the majority of resting state BDNF levels, a study of younger adult males found that there was a 200 to $300 \%$ increase in circulating BDNF levels during aerobic exercise, with an equivalent increase in the amount produced by the brain. However, this percentage contribution did decrease following 1 hour of recovery [126]. As a corollary to these finding, a review of previous studies concluded that peripheral BDNF may actually be transported back to, and used in, the brain after exercise [129].

Meta-analytic examination of 14 studies found that that a single aerobic exercise session increased circulating BDNF levels, and that the magnitude of this effect was greater in those who exercised regularly in comparison to those engaging in acute exercise only. However, sex moderated this effect, with men showing a significantly greater increase in BDNF levels than women [109]. This pattern of a short-lived increase in circulating BDNF following acute aerobic exercise has been found in numerous other studies, although similar effects have not been reliably found for strength/resistance based exercise [130]. An earlier review found that the increase in circulating levels of BDNF following exercise was transitory, and that levels returned to base line within a short period [129]. Conversely, more recent meta-analysis across
13 studies has demonstrated that regular exercise significantly increases resting BDNF levels, although this finding was not considered to be as robust as those regarding acute level increases [109]. Overall, there is reliable evidence, in humans, to advocate that each episode of aerobic exercise results in an acute increase in BDNF and that this response can be improved by regular physical exercise. However, the relative importance of the acute increase verses the smaller resting increase that results from regular exercise, as well as the difference in effect between males and females, is yet to be determined.

\section{Stress}

Exposure to stressors results in the activation of two distinct systems, the sympathetic nervous system (SNS) and the hypothalamus-pituitary-adrenal (HPA) axis. While the rapidly acting SNS primarily releases catecholamines (adrenaline and noradrenaline), the slower HPA axis releases glucocorticoids (primarily cortisol) [131]. The glucocorticoids can cross the $\mathrm{BBB}$ and enter the brain, where they bind with receptors, particularly in the frontal lobes, amygdala, and hippocampus, which have higher receptor density and are also central to cognition [132]. However, the catecholomines are unable to cross the BBB, and influence the brain via activation of intermediate signaling pathways, such as the vagus nerve, that stimulate noradrenergic pathways [133]. The interaction between these systems is responsible for facilitating a wide variety of stress mediated actions on cognition [134]. This process is generally positively adaptive in nature, promoting the cognitive processing and storage of salient information; however it can become maladaptive under certain circumstances and, conversely, interfere with memory and cognition [135].

While stress is a significant factor in cognitive performance, the defining factor in the influence of stress is its intensity and duration. Mild acute stress facilitates cognition, particularly when the cognitive load of the task is not too high. However, when the level of stress is high and/or chronically sustained, fluid cognitive performance is noticeably impaired, particularly in cognitive processes that are primarily dependent on the hippocampal or pre-frontal cortex (for comprehensive overview see [134]). When subjected to chronic physical, social, or pharmacological stressors, animal models, both rodent and primate, have demonstrated structural adult hippocampal changes including reduced neurogenesis, shortening 
of dendrites, and a loss of synapses, even at what was considered mild stress levels [136, 137]. The glucocorticoid hypothesis proposes that prolonged stress results in reduced negative feedback of cortisol, causing elevated glucocorticoids and eventual damage from prolonged exposure, particularly in the hippocampus [138]. Conversely, longitudinal human studies have found that the use of medical interventions (such as SSRIs, lithium, and electro-convulsive therapy) in treating either stress or depression disorders, have been linked to an increase in hippocampal volume following the course of treatment [139-142]. These findings indicate that the stress-related neurodegenerative process is somewhat reversible. Additionally, animal studies in this area have demonstrated that the effect of increased neurogenesis associated with antidepressants only occurs when the subjects are stressed [137], suggesting that it is the amelioration of stress that improves hippocampal neurogenesis, rather than a direct effect of the treatments.

Recent studies have demonstrated a relationship between anxiety (which is strongly associated both psychologically and physiologically with stress [143, 144]) and reduced cognitive performance in areas such verbal fluency, executive functioning, and memory in older people without dementia [145-147]. Again, as with the findings related to neurogenesis, amelioration of anxiety in older individuals through pharmacological intervention has been shown to improve executive function and episodic memory [148]. However, sex differences have been found, with cognitive impairment associated with anxiety to a greater degree in men than women [146]. Additionally, in patients with MCI, higher levels of self-reported stress are associated with a more rapid decline in cognitive performance than their counterparts who reported low stress levels [149]. Furthermore, higher levels of stress have also been related to an increased risk of developing dementia $[13,52]$.

In both humans and animals, those who engage in regular aerobic exercise have a significantly lower likelihood of suffering from stress associated disorders $[150,151]$. Specifically, earlier meta-analytic reviews found that regular, moderate-to-high intensity, aerobic exercise of 20 minutes or more in duration was anxiolytic, while shorter duration or non-aerobic exercise appeared to have little to no significant effect [152]. Additionally, duration appears to be important, with the greatest anxiety reduction occurring in exercise programs which last at least 15 weeks [153]. A more recent meta-analysis of 49 clinical trials also found that, across all age groups, exercise interventions were associated with a reduction in anxiety [154]. However, it also found that any duration or intensity of aerobic exercise reduced symptoms of anxiety, although there still appeared to be a dose-response relationship. Additionally, this review found that exercise was equally as effective in reducing anxiety as psychological intervention, and almost as effective as pharmacological interventions [154].

It has been proposed that voluntary exercise may ameliorate the impacts or effects of stress in a number of ways, both psychologically and physiologically [155]. Physiologically, exercise appears to reduce reaction to stress through mechanisms such as adaptations in the noradrenaline, serotonin and gamma-aminobutyric acid (GABA) neurotransmitter systems, although the majority of evidence in this area has been derived from rodent models [151, 156, 157]. Psychologically, effects such as improved self-esteem and sense of wellbeing related to improvement or maintenance of physical fitness and achievement of fitness goals, and the placebo effect of expected improvement in mental health, may also alleviate chronic stress and sensitivity to stressors (see [155] and [158] for reviews). However, while there is evidence that regular exercise does positively affect the pathophysiological effects of stress, no single mechanism appears to completely account for the observed effects. It is more probable that a combination of some or all of these proposed pathways are involved in stress attenuation, warranting further research in this area, particularly in humans.

\section{Inflammation}

Chronic inflammation is associated with increased risk of developing many chronic diseases such as cardiovascular disease [159], type 2 diabetes [160], and several types of cancer [161]. Infection or injury begins a cascade of local and systemic response events, including the production of pro-inflammatory cytokines. Interleukin-1 beta (IL-1 $\beta$ ) plays a central role in these responses by increasing the production of lymphocytes and initiating the elimination of damaged cells or pathogens by natural killer cells. IL-1 $\beta$ also stimulates the production of additional cytokines such as interleukin-6 (IL-6) and tumor necrosis factor-alpha (TNF- $\alpha$ ), which in turn affect other cells [162]. There is extensive intercommunication between the peripheral immune system and the CNS, through both neural pathways and via 
active transport across the $\mathrm{BBB}$. As a result of this communication, challenge to the peripheral immune system stimulates immune responses within the brain, which is primarily mediated by microglial cells [163]. Conversely, neurological damage also induces cytokine production peripherally $[164,165]$.

Microglia, the primary mediators of the immune response in the CNS, are normally quiescent unless the immune system perceives a threat [166]. Once activated, they multiply, undergo morphological changes, and produce pro-inflammatory cytokines until the threat is resolved [167]; whereupon they produce anti-inflammatory cytokines and other factors to re-establish homeostasis [166]. Animal studies have shown that this neuroinflammatory response becomes sensitized in normal aging, with the hippocampus demonstrating a more exaggerated immune response to challenge, with this elevated production of proinflammatory cytokines occurring for a longer period of time once the challenge has passed $[168,169]$. This is supported by human studies demonstrating that aging is associated with a two- to four-fold increase in circulating systemic levels of inflammatory mediators across the lifespan [170].

There is an increasing accumulation of evidence that supports the contention that activation of the peripheral immune system is associated with cognitive dysfunction $[162,171]$ and, more specifically, that neurogenesis is impaired by neuroinflammation, leading to poorer cognitive functioning [27]. In their seminal paper, Monje, Toda, and Palmer [172] found that inflammation alone, following cranial radiation therapy, inhibited neurogenesis, leading to progressive cognitive decline; and that preventing inflammation through the use of pharmacological anti-inflammatories restored neurogenesis and ameliorated further cognitive deterioration. Animal research has demonstrated that memory impairment resulting from orthopedic surgery was associated with increased levels of not only circulating, but also hippocampally-produced inflammatory factors [173]. Furthermore, inhibition of IL-1 $\beta$ ameliorated both the hippocampal inflammation and the cognitive dysfunction [174]. Additionally, on a structural level, circulating levels of IL-6 have been found to inversely co-vary with hippocampal grey matter volume [171].

These findings have been supported by analyses of data from several large prospective cohort studies [175-177], which have found that higher levels of systemic markers of inflammation (IL-6 and C-Reactive Protein; CRP) were associated with both lower initial cognitive function and greater risk of cognitive decline at follow-up. Interestingly, not all studies in this area have found consistent results, with a couple of similarly sized studies finding little to no evidence to support these contentions [178, 179]. However, one of these studies [178] did not assess cognition at baseline or inflammatory markers at follow-up; and the other [179] used a relatively low sensitivity assay for IL-6, which they acknowledge may have influenced the results.

Additionally, findings from dementia research also support the role of inflammation in cognitive dysfunction, with higher circulatory CRP at midlife shown to be associated with significantly greater risk for dementia 25 years later in a large sample of 1,000 people [180]. This relationship was independent of potential confounding variables, except for a partially mediated relationship with subclinical atherosclerosis, and the temporal distance between assessments significantly reduces the likelihood that inflammation was symptomatic of pre-clinical $\mathrm{AD}$, rather than a causative factor. Additionally, genetic polymorphisms that reduce circulating IL-6 have been associated with both delayed initial onset and reduced incidence of AD [181], indicating that inflammation may play a key role in the development of neurodegenerative disease. Interestingly, however, the use of pharmacological anti-inflammatories to slow or prevent neurodegenerative disease has produced varied results [182]. It has been suggested that neurodegeneration may also be slowed down by certain aspects of inflammation, particularly by increasing the recruitment of systemic immune cells, such as T-cells and monocytes, across the BBB, which may modify the potentially destructive effects of localized CNS inflammation [182].

Physical activity has become increasingly recognized as a potential intervention to reduce chronic inflammation [161, 183, 184]. Numerous large cohort studies have consistently found lower levels of systemic inflammatory biomarkers in those who either subjectively reported higher levels of physical activity or objectively demonstrated greater aerobic fitness [185-190]. Additionally, one small intervention trial found resistance training moderately reduced markers of inflammation in overweight women [191]. A similar result was also found for sedentary participants following a trial that used a combined aerobic and resistance training intervention [192]. However, intervention studies in general have produced inconsistent results, although this is likely to be related to a number of methodological reasons, such as being 
underpowered, lacking a control group and inconsistency of exercise interventions used (see [193] for review of both cohort and aerobic intervention studies). While the mechanisms underlying this antiinflammatory effect are still far from clear, it is currently postulated that IL-6 production from skeletal muscles during exercise is a significant mediating factor. At rest, most of the circulating IL-6 is produced from adipose tissue and leucocytes, with very little produced from skeletal muscles, but during moderate (equivalent to vigorous walking) to intense exercise, circulating IL-6 can increase up to 100 -fold [183].

However, while usually considered to be proinflammatory, the IL-6 produced by skeletal muscles during exercise appears unique in that it suppresses the production of other pro-inflammatory cytokines, such as TNF- $\alpha$ and IL-1 $\beta$. Furthermore, exercise-induced IL-6 stimulates the release of anti-inflammatory cytokines, which may result in an overall lowering of chronic inflammation over time. Muscle-derived IL-6 is also proposed to be involved in stimulating the production of cortisol and adrenaline during exercise, which have strong, acute anti-inflammatory properties [194, 195]. Additional exercise-induced anti-inflammatory mediators have also been postulated, although they have not been as well studied to date (see [195] for review). Overall, it is this reduction in systemic inflammation that is proposed to reduce the associated neuro-inflammatory processes and the associated negative influence on cognitive function.

\section{Insulin regulation}

Insulin, produced by pancreatic beta cells, is the hormone central to regulating the level of blood glucose in the body. When bound to an insulin receptor (IR) it regulates the cellular uptake of glucose by the activation of glucose transporters, which is then used as either fuel for energy or stored. Insulin also plays a role in uptake of amino acids and their incorporation into proteins, as well as reducing the rate of catabolism [196]. Although it was initially believed that the brain was insensitive to insulin, animal experiments in the 1960s demonstrated that insulin also promoted the uptake of glucose in CNS tissue $[197,198]$. Following these observations, subsequent researchers suggested that insulin in the brain may work solely as it does in peripheral tissue, by mediating the uptake of glucose into the cells and thus regulating their production of energy. Therefore, reduced IR sensitivity would lead to starving the neurons of glucose and subsequent neuronal dysfunction, effectively "diabetes of the brain" [199]. However, more recent research has demonstrated that only a small percentage of the glucose used by the brain is actually obtained via insulin-dependent transport mechanisms [200], with the insulin-insensitive glucose transporters, being the main ones expressed in the CNS [201]. Furthermore, there is an uneven distribution of IRs throughout the brain, indicating specific CNS functionality in addition to the overall supply of glucose [200].

Primarily based on animal studies, IRs in the brain have been found to be concentrated in a number of neural regions highly associated with memory, learning, and cognition: specifically the hippocampus, amygdala, and cerebral cortex [202-207]. While not as well investigated, these findings have also been supported by a few small postmortem human studies $[200,208]$. Given the role of insulin in peripheral glucose regulation, and the distributions of the receptors, insulin may exert its effect on memory and cognition in a similar way in the CNS. However, it is also likely to affect cognitive functioning through a number of other non-metabolic mechanisms.

Insulin is also an important neuromodulator [209], affecting both synaptic and post-synaptic activity, particularly through its ability to modulate signaling by potentiating NMDA, AMPA, and GABA receptors [210]. These receptors are known to play important roles in synaptic plasticity, learning, and memory [211, 212]. Insulin and IRs have also been found to influence numerous other processes in the brain which are likely to affect cognitive performance, such as neuronal proliferation [213] and differentiation [214-216], protection from apoptosis [213, 217], and both inhibition and excitation of neuronal firing through effects on ion channels [212, 218] (see [196] for review of the functions of insulin in the brain).

While there is limited evidence for the idea of de novo synthesis of insulin in the brain [219-221], to date this has not been conclusively demonstrated in humans or higher order animals, and is particularly inconclusive in adult brains [222-224]. However, although lipid insoluble, insulin readily crosses the BBB from the peripheral circulatory system via an IR-mediated saturable transport system [223, 225, 226]. CSF insulin levels have been demonstrated to increase following acute elevation of circulating insulin [227], highlighting this interrelationship between peripheral and central insulin. Overall then, the brain appears to rely predominantly, if not 
completely, on peripherally produced insulin for its insulin dependent functions.

Although acute high levels of insulin have been shown to benefit cognition $[228,229]$, chronic hyperinsulinemia is likely to negatively affect cognitive functioning. Persistently high levels of insulin reduce the sensitivity of peripheral IRs, including those in the BBB. This reduces the amount of insulin transported to the brain from the peripheral system [230], resulting in a reduction in overall availability of insulin in the brain [231]. Additionally, peripheral insulin resistance has also been linked to insulin resistance in the brain [232, 233]. Significantly reduced sensitivity to insulin is the central aspect of type 2 diabetes, but increased insulin resistance is also associated with both obesity and aging [234, 235].

Numerous investigations have found an association between insulin resistance and both faster rates of cognitive decline and increased risk of cognitive impairment in older populations [236-238]. Several studies also indicate that cognitive functions may be impaired before the dysfunction of the glucoregulatory system reaches the threshold for a diagnosis of type 2 diabetes [239, 240]. Insulin resistance is also associated with increased risk of $\mathrm{AD}$ as well as age-associated memory dysfunction [231]. Reduced IR density and insulin sensitivity in the brain have been found to be related to the two major pathological mechanisms currently associated with $\mathrm{AD}$ : increased accumulation of $A \beta$ and tau protein hyperphosphorylation (see [241] and [30] for reviews on insulin and $\mathrm{AD}$ ). Conversely, intranasal administration (enabling the bypassing of the BBB) of a long lasting insulin analogue has actually been shown to improve cognitive functioning in participants with MCI and those with mild to moderate AD [242]. Additionally, this relationship between insulin resistance and cognitive decline is further highlighted by conditions commonly associated with dysfunctional insulin sensitivity, such as, hyperglycemia [241], dyslipidemia, hypertension, and obesity [29]. These conditions are all considered insulin resistance related disorders and, particularly when present in middle age, each represents an elevated risk for accelerated cognitive decline and dementia [29, 241].

A sedentary lifestyle is very likely to be a crucial aspect in the ever-increasing incidence of insulin resistance in the population [30]. A study of male endurance trained athletes, predominantly cyclists and runners, found that they had better insulin sensitivity than sedentary men, and, remarkably, there was no difference in insulin sensitivity between those in their 20s and those in their 60s. However, sedentary older men in this study had significantly lower insulin sensitivity than younger sedentary men [243]. This study provides evidence that exercise-at least long-term, regular, intensive exercise-can prevent the reduction in insulin sensitivity associated with increasing age. Additionally, when compared to a stretching-only control group, six months of regular aerobic exercise in a glucose-intolerant older cohort was found to improve multiple aspects of cognition, while concurrently improving insulin sensitivity and reducing circulating levels of $A \beta$ [28]. A recent review covering 40 years of research examining exercise biomarkers in participants with $\mathrm{MCI}$ and dementia found only two studies had assessed insulin sensitivity [244]. Both of these studies found better cognitive outcomes for the exercise groups compared to control. However, while one study, which involved six months of regular high intensity exercise, found improvements in insulin sensitivity [245], the other study used a less vigorous intervention of tai-chi over only 12 weeks and found no such improvement [246]. Despite limited research in this area, it appears that exercise may improve insulin sensitivity and cognitive outcomes for those with MCI or early dementia, but that the exercise must be sufficiently aerobic and intensive to be effective. However, it is evident that more research is required to draw firm conclusions.

Overall, specific research examining insulin sensitivity as a mechanism involved in the interplay between exercise and cognition is quite limited, with relatively few studies and small cohorts. However, while not looking explicitly at cognition, physical activity in general appears to be an important, if not an essential, element in the reduction and prevention of insensitivity to insulin [247]. More specifically, Mann et al. [248] systematically reviewed the interventional research into the responses of insulin sensitivity to different modalities of exercise. They concluded that both aerobic exercise and resistance training were effective in improving insulin sensitivity, and that combining the two was the most efficient strategy. It is worth noting that, at present, although the overall evidence is quite strong, there have been considerably more investigations conducted with aerobic interventions than resistance or combination training; and more research is warranted in these areas. This conclusion matches closely with the overall evidence available from research into the exercise-cognitioninsulin axis. 


\section{CONCLUSION}

There is a large body of evidence indicating that physical exercise has a beneficial effect on cognitive performance and the rate of cognitive aging. More specifically, the extant literature suggests that all of the reviewed mechanisms are likely to play a role in mediating the relationship between exercise and cognition. However, at present, the majority of research in these areas has focused on aerobic exercise. Therefore, while the weight of evidence suggests benefits from aerobic exercise, further research into the effect of resistance or combined exercise on these mechanisms and cognition is warranted.

The intensity and duration of exercise are also proposed to have a dose effect on both the mechanisms and positive cognitive outcomes. While increasing levels of physical exercise have been reported to exert greater impacts on cognition, the evidence for this dose-response is not comprehensive; as to date, no study has established a strong case for a precise relationship. Additionally, the mechanisms reviewed do not exist in isolation, with each one affecting the other to some degree (e.g., [160, 196, 249, 250]). Again, considerations of these relationships in future research are highly recommended in order to develop a more comprehensive understanding of the relationship between exercise and cognitive aging.

Overall, the current research supports the potential for exercise to improve cognitive outcomes via increased BDNF-facilitated neurogenesis and neuroplasticity, improvement in vascular function, reduced stress and inflammation, and improved insulin sensitivity. However, at present the relative contribution of exercise to these mechanisms has not been specified. Neither have the relative strengths of the influence of these mechanisms on cognition, as current research in the area typically isolates one specific potential mediator at a time. Exercise, as opposed to many other potential cognitive interventions, is extremely costeffective and has no intrinsic negative side effects, which makes it a promising candidate for ameliorating the rate of cognitive decline in our aging population. Furthermore, as each of these potential mechanisms has established, quantifiable biomarkers, future research would benefit by establishing the relative strengths of these mechanisms, and the consistency of their effect on cognition. Research of this type is needed to help inform investigation into the efficacy of various exercise intervention programs and their potential to affect cognitive outcomes.

\section{ACKNOWLEDGMENTS}

The authors would like to thank Lee Lawrence, Jeff Reddan, Ian Kennedy, Sandra Hacker and Matthew Pase for their constructive feedback on the draft of this manuscript.

Authors' disclosures available online (http://jalz.com/manuscript-disclosures/16-0665r1).

\section{REFERENCES}

[1] Vaynman S, Gomez-Pinilla F (2006) Revenge of the "Sit": How lifestyle impacts neuronal and cognitive health through molecular systems that interface energy metabolism with neuronal plasticity. J Neurosci Res $\mathbf{8 4}$, 699-715.

[2] Hallal PC, Andersen LB, Bull FC, Guthold R, Haskell W, Ekelund U (2012) Global physical activity levels: Surveillance progress, pitfalls, and prospects. Lancet 380, 247-257.

[3] Blair SN, Kohl HW, Paffenbarger RS, Clark DG, Cooper KH, Gibbons LW (1989) Physical fitness and all-cause mortality: A prospective study of healthy men and women. JAMA 262, 2395-2401.

[4] Miller TD, Balady GJ, Fletcher GF (1997) Exercise and its role in the prevention and rehabilitation of cardiovascular disease. Ann Behav Med 19, 220-229.

[5] Chodzko-Zajko WJ, Proctor DN, Fiatarone Singh MA, Minson CT, Nigg CR, Salem GJ, Skinner JS (2009) American College of Sports Medicine position stand. Exercise and physical activity for older adults. Med Sci Sports Exerc 41, 1510-1530.

[6] Södergren M (2013) Lifestyle predictors of healthy ageing in men. Maturitas 75, 113-117.

[7] Gebel K, Ding D, Chey T, Stamatakis E, Brown WJ, Bauman AE (2015) Effect of moderate to vigorous physical activity on all-cause mortality in middle-aged and older Australians. JAMA Intern Med 175, 970-977.

[8] Colcombe SJ, Erickson KI, Raz N, Webb AG, Cohen NJ, McAuley E, Kramer AF (2003) Aerobic fitness reduces brain tissue loss in aging humans. J Gerontol A Biol Sci Med Sci 58, 176-180.

[9] Colcombe SJ, Kramer AF, Erickson KI, Scalf P, McAuley E, Cohen NJ, Webb A, Jerome GJ, Marquez DX, Elavsky S (2004) Cardiovascular fitness, cortical plasticity, and aging. Proc Natl Acad Sci U S A 101, 3316-3321.

[10] Kramer AF, Erickson KI, Colcombe SJ (2006) Exercise, cognition, and the aging brain. J Appl Physiol 101, 1237 1242.

[11] Weinberg RS, Gould D (2015) Foundations of Sport and Exercise Psychology, Human Kinetics, Champaign, IL.

[12] Etnier JL, Nowell PM, Landers DM, Sibley BA (2006) A meta-regression to examine the relationship between aerobic fitness and cognitive performance. Brain Res Rev 52, 119-130.

[13] van Uffelen JGZ, Chin A, Paw MJM, Hopman-Rock M, van Mechelen W (2008) The effects of exercise on cognition in older adults with and without cognitive decline: A systematic review. Clin J Sport Med 18, 486-500.

[14] Kelly ME, Loughrey D, Lawlor BA, Robertson IH, Walsh C, Brennan S (2014) The impact of exercise on the cognitive functioning of healthy older adults: A systematic review and meta-analysis. Ageing Res Rev 16, 12-31. 
[15] Cotman CW, Berchtold NC (2002) Exercise: A behavioral intervention to enhance brain health and plasticity. Trends Neurosci 25, 295-301.

[16] Vaynman S, Ying Z, Gomez-Pinilla F (2004) Hippocampal BDNF mediates the efficacy of exercise on synaptic plasticity and cognition. Eur J Neurosci 20, 2580-2590.

[17] Gomez-Pinilla F, Vaynman S, Ying Z (2008) Brain-derived neurotrophic factor functions as a metabotrophin to mediate the effects of exercise on cognition. Eur J Neurosci 28, 2278-2287.

[18] Weinstein G, Beiser AS, Choi SH, Preis SR, Chen TC, Vorgas D, Au R, Pikula A, Wolf PA, DeStefano AL, Vasan RS, Seshadri S (2014) Serum brain-derived neurotrophic factor and the risk for dementia: The Framingham Heart Study. JAMA Neurol 71, 55-61.

[19] Bolduc V, Thorin-Trescases N, Thorin E (2013) Endothelium-dependent control of cerebrovascular functions through age: Exercise for healthy cerebrovascular aging. Am J Physiol Heart Circ Physiol 305, H620-H633.

[20] Tarumi T, Gonzales MM, Fallow B, Nualnim N, Pyron M, Tanaka H, Haley AP (2013) Central artery stiffness, neuropsychological function, and cerebral perfusion in sedentary and endurance-trained middle-aged adults. $J$ Hypertens 31, 2400-2409.

[21] Lessiani G, Santilli F, Boccatonda A, Iodice P, Liani R, Tripaldi R, Saggini R, Daví G (2016) Arterial stiffness and sedentary lifestyle: Role of oxidative stress. Vascul Pharmacol 79, 1-5.

[22] Tsatsoulis A, Fountoulakis S (2006) The protective role of exercise on stress system dysregulation and comorbidities. Ann N Y Acad Sci 1083, 196-213.

[23] Head D, Singh T, Bugg JM (2012) The moderating role of exercise on stress-related effects on the hippocampus and memory in later adulthood. Neuropsychology 26, 133-143.

[24] Reul JMHM, Collins A, Saliba RS, Mifsud KR, Carter SD, Gutierrez-Mecinas M, Qian X, Linthorst ACE (2015) Glucocorticoids, epigenetic control and stress resilience. Neurobiol Stress 1, 44-59.

[25] Packer N, Pervaiz N, Hoffman-Goetz L (2010) Does exercise protect from cognitive decline by altering brain cytokine and apoptotic protein levels? A systematic review of the literature. Exerc Immunol Rev 16, 138-162.

[26] Svensson M, Lexell J, Deierborg T (2015) Effects of physical exercise on neuroinflammation, neuroplasticity, neurodegeneration, and behavior: What we can learn from animal models in clinical settings. Neurorehabil Neural Repair 29, 577-589.

[27] Ryan SM, Nolan YM (2016) Neuroinflammation negatively affects adult hippocampal neurogenesis and cognition: Can exercise compensate? Neurosci Biobehav Rev 61, 121-131.

[28] Baker LD, Frank LL, Foster-Schubert K, Green PS, Wilkinson CW, McTiernan A, Cholerton BA, Plymate SR, Fishel MA, Watson GS, Duncan GE, Mehta PD, Craft S (2010) Aerobic exercise improves cognition for older adults with glucose intolerance, a risk factor for Alzheimer's disease. J Alzheimers Dis 22, 569-579.

[29] Cholerton B, Baker LD, Craft S (2011) Insulin resistance and pathological brain ageing. Diabet Med 28, 1463-1475.

[30] Craft S, Cholerton B, Baker LD (2013) Insulin and Alzheimer's disease: Untangling the web. J Alzheimers Dis 33, S263-S275.

[31] Colcombe S, Kramer A (2003) Fitness effects on the cognitive function of older adults a meta-analytic study. Psychol Sci 14, 125-130.
[32] Ruscheweyh R, Willemer C, Krüger K, Duning T, Warnecke T, Sommer J, Völker K, Ho HV, Mooren F, Knecht S, Flöel A (2011) Physical activity and memory functions: An interventional study. Neurobiol Aging 32, 13041319.

[33] Gomez-Pinilla F, Hillman C (2013) The influence of exercise on cognitive abilities. Compr Physiol 3, 403-428.

[34] Rockwood K, Middleton L (2007) Physical activity and the maintenance of cognitive function. Alzheimers Dement 3, S38-S44.

[35] Jedrziewski MK, Ewbank DC, Wang H, Trojanowski JQ (2010) Exercise and cognition: Results from the National Long Term Care Survey. Alzheimers Dement 6, 448455.

[36] Lee Y, Back JH, Kim J, Kim S-H, Na DL, Cheong H-K, Hong CH, Kim YG (2010) Systematic review of health behavioral risks and cognitive health in older adults. Int Psychogeriatrics 22, 174-187.

[37] Blondell SJ, Hammersley-Mather R, Veerman JL (2014) Does physical activity prevent cognitive decline and dementia?: A systematic review and meta-analysis of longitudinal studies. BMC Public Health 14, 510.

[38] Sofi F, Valecchi D, Bacci D, Abbate R, Gensini GF, Casini A, Macchi C (2011) Physical activity and risk of cognitive decline: A meta-analysis of prospective studies. J Intern Med 269, 107-117.

[39] Weuve J, Kang JH, Manson JE, Breteler MMB, Ware JH, Grodstein F (2004) Physical activity, including walking, and cognitive function in older women. JAMA 292, 14541461.

[40] Smith PJ, Blumenthal JA, Hoffman BM, Strauman TA, Welsh-bohmer K, Jeffrey N, Sherwood A (2010) Aerobic exercise and neurocognitive performance: A meta- analytic review of randomized controlled trials. Psychosom Med 72, 239-252.

[41] Pipingas A, Harris E, Tournier E, King R, Kras M, Stough CK (2010) Assessing the efficacy of nutraceutical interventions on cognitive functioning in the elderly. Curr Top Nutraceutical Res 8, 79-88.

[42] Heyn P, Abreu BC, Ottenbacher KJ (2004) The effects of exercise training on elderly persons with cognitive impairment and dementia: A meta-analysis. Arch Phys Med Rehabil 85, 1694-1704.

[43] Lautenschlager NT, Cox K, Kurz AF (2010) Physical activity and mild cognitive impairment and Alzheimer's disease. Curr Neurol Neurosci Rep 10, 352-358.

[44] Erickson KI, Voss MW, Prakash RS, Basak C, Szabo A, Chaddock L, Kim JS, Heo S, Alves H, White SM, Wojcicki TR, Mailey E, Vieira VJ, Martin SA, Pence BD, Woods JA, McAuley E, Kramer AF (2011) Exercise training increases size of hippocampus and improves memory. Proc Natl Acad Sci U S A 108, 3017-3022.

[45] Ohman H, Savikko N, Strandberg TE, Pitkälä KH (2014) Effect of physical exercise on cognitive performance in older adults with mild cognitive impairment or dementia: A systematic review. Dement Geriatr Cogn Disord 38, 347-365.

[46] Vidoni ED, Johnson DK, Morris JK, Van Sciver A, Greer CS, Billinger SA, Donnelly JE, Burns JM (2015) Doseresponse of aerobic exercise on cognition: A communitybased, pilot randomized controlled trial. PLoS One 10, 1-14.

[47] Gajewski PD, Falkenstein M (2016) Physical activity and neurocognitive functioning in aging - a condensed updated review. Eur Rev Aging Phys Act 13, 1. 
[48] Casserly I, Topol E (2004) Convergence of atherosclerosis and Alzheimer's disease: Inflammation, cholesterol, and misfolded proteins. Lancet 363, 1139-1146.

[49] de la Torre JC (2002) Alzheimer disease as a vascular disorder: Nosological evidence. Stroke 33, 1152-1162.

[50] de la Torre JC (2004) Is Alzheimer's disease a neurodegenerative or a vascular disorder? Data, dogma, and dialectics. Lancet Neurol 3, 184-190.

[51] van Norden AGW, van Dijk EJ, de Laat KF, Scheltens P, Olderikkert MGM, de Leeuw FE (2012) Dementia: Alzheimer pathology and vascular factors: From mutually exclusive to interaction. Biochim Biophys Acta 1822, 340-349.

[52] Fratiglioni L, Paillard-borg S, Winblad B (2004) Review: An active and socially integrated lifestyle in late life might protect against dementia. Lancet Neurol 3, 343-353.

[53] Picano E, Bruno RM, Ferrari GF, Bonuccelli U (2014) Cognitive impairment and cardiovascular disease: So near, so far. Int J Cardiol 175, 21-29.

[54] Laurent S, Cockcroft J, Van Bortel L, Boutouyrie P, Giannattasio C, Hayoz D, Pannier B, Vlachopoulos C, Wilkinson I, Struijker-Boudier H (2006) Expert consensus document on arterial stiffness: Methodological issues and clinical applications. Eur Heart J 27, 2588-2605.

[55] Stone J, Johnstone DM, Mitrofanis J, Rourke MO (2015) The mechanical cause of age-related dementia (Alzheimer's disease): The brain is destroyed by the pulse. J Alzheimers Dis 44, 355-373.

[56] Laurent S, Boutouyrie P, Lacolley P (2005) Structural and genetic bases of arterial stiffness. Hypertension 45, 10501055.

[57] Wilkinson IB, McEniery CM (2012) Arteriosclerosis: Inevitable or self-inflicted? Hypertension 60, 3-5.

[58] Najjar SS, Scuteri A, Lakatta EG (2005) Arterial aging: Is it an immutable cardiovascular risk factor? Hypertension 46, 454-462.

[59] Mitchell GF (2008) Effects of central arterial aging on the structure and function of the peripheral vasculature: Implications for end-organ damage. J Appl Physiol 105, 1652-1660.

[60] O'Rourke MF, Safar ME (2005) Relationship between aortic stiffening and microvascular disease in brain and kidney: Cause and logic of therapy. Hypertension 46, 200204.

[61] Chirinos JA (2012) Arterial stiffness: Basic concepts and measurement techniques. J Cardiovasc Transl Res 5, 243255.

[62] Rabkin SW (2012) Arterial stiffness: Detection and consequences in cognitive impairment and dementia of the elderly. J Alzheimers Dis 32, 541-549.

[63] van Sloten TT, Protogerou AD, Henry RMA, Schram MT, Launer LJ, Stehouwer CDA (2015) Association between arterial stiffness, cerebral small vessel disease and cognitive impairment: A systematic review and meta-analysis. Neurosci Biobehav Rev 53, 121-130.

[64] Singer J, Trollor JN, Baune BT, Sachdev PS, Smith E (2014) Arterial stiffness, the brain and cognition: A systematic review. Ageing Res Rev 15, 16-27.

[65] O'Rourke MF (2007) Arterial aging: Pathophysiological principles. Vasc Med 12, 329-341.

[66] Cavalcante JL, Lima JAC, Redheuil A, Al-Mallah MH (2011) Aortic stiffness: Current understanding and future directions. J Am Coll Cardiol 57, 1511-1522.

[67] Aoyagi Y, Park H, Kakiyama T, Park S, Yoshiuchi K, Shephard RJ (2010) Yearlong physical activity and regional stiffness of arteries in older adults: The Nakanojo Study. Eur J Appl Physiol 109, 455-464.

[68] Heffernan KS, Collier SR, Kelly EE, Jae SY, Fernhall B (2007) Arterial stiffness and baroreflex sensitivity following bouts of aerobic and resistance exercise. Int J Sports Med 28, 197-203.

[69] Seals DR, Desouza CA, Donato AJ, Tanaka H (2008) Habitual exercise and arterial aging. J Appl Physiol 105, 1323-1332.

[70] Monahan KD, Tanaka H, Dinenno FA, Seals DR (2001) Central arterial compliance is associated with ageand habitual exercise-related differences in cardiovagal baroreflex sensitivity. Circulation 104, 1627-1632.

[71] Tanaka H, DeSouza CA, Seals DR (1998) Absence of agerelated increase in central arterial stiffness in physically active women. Arterioscler Thromb Vasc Biol 18, 127132.

[72] Braith RW, Stewart KJ (2006) Resistance exercise training: Its role in the prevention of cardiovascular disease. Circulation 113, 2642-2650.

[73] Barnes JN, Trombold JR, Dhindsa M, Lin H-F, Tanaka $\mathrm{H}$ (2010) Arterial stiffening following eccentric exerciseinduced muscle damage. J Appl Physiol 109, 11021108 .

[74] Iadecola C (2004) Neurovascular regulation in the normal brain and in Alzheimer's disease. Nat Rev Neurosci 5, 347360.

[75] Krnjević K (2008) Electrophysiology of cerebral ischemia. Neuropharmacology 55, 319-333.

[76] Bor-Seng-Shu E, Kita WS, Figueiredo EG, Paiva WS, Fonoff ET, Teixeira MJ, Panerai RB (2012) Cerebral hemodynamics: Concepts of clinical importance. Arq Neuropsiquiatr 70, 352-356.

[77] Sinn N, Howe P (2008) Mental health benefits of omega-3 fatty acids may be mediated by improvements in cerebral vascular function. Biosci Hypotheses 1, 103-108.

[78] Faraci FM, Heistad DD (1998) Regulation of the cerebral circulation: Role of endothelium and potassium channels. Physiol Rev 78, 53-97.

[79] Pluta RM (2005) Delayed cerebral vasospasm and nitric oxide: Review, new hypothesis, and proposed treatment. Pharmacol Ther 105, 23-56.

[80] Abbott NJ, Rönnbäck L, Hansson E (2006) Astrocyteendothelial interactions at the blood-brain barrier. Nat Rev Neurosci 7, 41-53.

[81] Toda N (2012) Age-related changes in endothelial function and blood flow regulation. Pharmacol Ther 133, 159-176.

[82] Virdis A, Ghiadoni L, Giannarelli C, Taddei S (2010) Endothelial dysfunction and vascular disease in later life. Maturitas 67, 20-24.

[83] Naiberg MR, Newton DF, Goldstein BI (2016) Flowmediated dilation and neurocognition: Systematic review and future directions. Psychosom Med 78, 192-207.

[84] Katusic ZS, Austin SA (2014) Endothelial nitric oxide: Protector of a healthy mind. Eur Heart J 35, 888-894.

[85] DeSouza CA, Shapiro LF, Clevenger CM, Dinenno FA, Monahan KD, Tanaka H, Seals DR (2000) Regular aerobic exercise prevents and restores age-related declines in endothelium-dependent vasodilation in healthy men. Circulation 102, 1351-1357.

[86] Ashor AW, Lara J, Siervo M, Celis-Morales C, Oggioni C, Jakovljevic DG, Mathers JC (2015) Exercise modalities and endothelial function: A systematic review and dose-response meta-analysis of randomized controlled trials. Sport Med 45, 279-296. 
[87] Rauramaa R, Hassinen M (2011) Exercise training and endothelial function. Curr Cardiovasc Risk Rep 5, 323330 .

[88] Montero D (2015) The association of cardiorespiratory fitness with endothelial or smooth muscle vasodilator function. Eur J Prev Cardiol 22, 1200-1211.

[89] Di Francescomarino S, Sciartilli A, Di Valerio V, Di Baldassarre A, Gallina S (2009) The effect of physical exercise on endothelial function. Sport Med 39, 797-812.

[90] Ross MD, Malone E, Florida-James G (2015) Vascular ageing and exercise: Focus on cellular reparative processes. Oxid Med Cell Longev 2016, 18-20.

[91] Ploughman M (2008) Exercise is brain food: The effects of physical activity on cognitive function. Dev Neurorehabil 11, 236-240.

[92] Jolla L (1998) Neurogenesis in the adult human hippocampus. Nat Med 4, 1313-1317.

[93] Spellman T, Rigotti M, Ahmari SE, Fusi S, Gogos JA, Gordon JA (2015) Hippocampal-prefrontal input supports spatial encoding in working memory. Nature 522, 309314.

[94] Basso JC, Shang A, Elman M, Karmouta R, Suzuki WA (2015) Acute exercise improves prefrontal cortex but not hippocampal function in healthy adults. J Int Neuropsychol Soc 21, 791-801.

[95] Voss MW, Vivar C, Kramer AF, van Praag H (2013) Bridging animal and human models of exercise-induced brain plasticity. Trends Cogn Sci 17, 525-544.

[96] Zainuddin MSA, Thuret S (2012) Nutrition, adult hippocampal neurogenesis and mental health. Br Med Bull 103, 89-114.

[97] Carvalho A, Rea IM, Parimon T, Cusack BJ (2014) Physical activity and cognitive function in individuals over 60 years of age: A systematic review. Clin Interv Aging 9, 661-682.

[98] Vaynman S, Gomez-Pinilla F (2005) License to run: Exercise impacts functional plasticity in the intact and injured central nervous system by using neurotrophins. Neurorehabil Neural Repair 19, 283-295.

[99] Tapia-Arancibia L, Aliaga E, Silhol M, Arancibia S (2008) New insights into brain BDNF function in normal aging and Alzheimer disease. Brain Res Rev 59, 201-220.

[100] Tapia-Arancibia L, Rage F, Givalois L, Arancibia S (2004) Physiology of BDNF: Focus on hypothalamic function. Front Neuroendocrinol 25, 77-107.

[101] Hertzog C, Kramer AF, Wilson RS, Lindenberger U (2009) Enrichment effects on adult cognitive development: Can the functional capacity of older adults be preserved and enhanced? Psychol Sci Public Interest 9, 1-66.

[102] Song J-H, Yu J-T, Tan L (2014) Brain-derived neurotrophic factor in Alzheimer's disease: Risk, mechanisms, and therapy. Mol Neurobiol 52, 1477-1493.

[103] Lu B, Nagappan G, Lu Y (2014) BDNF and synaptic plasticity, cognitive function, and dysfunction. Handb Exp Pharmacol 220, 223-250.

[104] Korte M, Carroll P, Wolf E, Brem G, Thoenen H, Bonhoeffer T (1995) Hippocampal long-term potentiation is impaired in mice lacking brain-derived neurotrophic factor. Proc Natl Acad Sci U S A 92, 8856-8860.

[105] Patterson SL, Abel T, Deuel TAS, Martin KC, Rose JC, Kandel ER (1996) Recombinant BDNF rescues deficits in basal synaptic transmission and hippocampal LTP in BDNF knockout mice. Neuron 16, 1137-1145.

[106] Kang H, Welcher AA, Shelton D, Schuman EM (1997) Neurotrophins and time: Different roles for TrkB signaling in hippocampal long-term potentiation. Neuron 19, 653664.

[107] Chen G, Kolbeck R, Barde YA, Bonhoeffer T, Kossel A (1999) Relative contribution of endogenous neurotrophins in hippocampal long-term potentiation. J Neurosci 19, 7983-7990.

[108] Kemppainen S, Rantamäki T, Jerónimo-Santos A, Lavasseur G, Autio H, Karpova N, Kärkkäinen E, Stavén S, Miranda HV, Outeiro TF, Diógenes MJ, Laroche S, Davis S, Sebastião AM, Castrén E, Tanila H (2012) Impaired TrkB receptor signaling contributes to memory impairment in APP/PS1 mice. Neurobiol Aging 33, 1122.e23-1122.e39.

[109] Szuhany KL, Bugatti M, Otto MW (2015) A meta-analytic review of the effects of exercise on brain-derived neurotrophic factor. $J$ Psychiatr Res 60, 56-64.

[110] Van Praag H (2008) Neurogenesis and exercise: Past and future directions. NeuroMolecular Med 10, 128-140.

[111] Murer M, Yan Q, Raisman-Vozari R (2001) Brain-derived neurotrophic factor in the control human brain, and in Alzheimer's disease and Parkinson's disease. Prog $\mathrm{Neu}$ robiol 63, 71-124.

[112] Zuccato C, Ciammola A, Rigamonti D, Leavitt BR, Goffredo D, Conti L, MacDonald ME, Friedlander RM, Silani V, Hayden MR, Timmusk T, Sipione S, Cattaneo E (2001) Loss of huntingtin-mediated BDNF gene transcription in Huntington's disease. Science 293, 493-498.

[113] Yasutake C, Kuroda K, Yanagawa T, Okamura T, Yoneda $\mathrm{H}$ (2006) Serum BDNF, TNF- $\alpha$ and and IL-1 $\beta$ levels in dementia patients: Comparison between Alzheimer's disease and vascular dementia. Eur Arch Psychiatry Clin Neurosci 256, 402-406.

[114] Borroni B, Bianchi M, Premi E, Alberici A, Archetti S, Paghera B, Cerini C, Papetti A, Padovani A (2012) The brain-derived neurotrophic factor val66met polymorphism is associated with reduced hippocampus perfusion in frontotemporal lobar degeneration. J Alzheimers Dis 31, 243-251.

[115] Egan MF, Kojima M, Callicott JH, Goldberg TE, Kolachana BS, Bertolino A, Zaitsev E, Gold B, Goldman D, Dean M, Lu B, Weinberger DR (2003) The BDNF val66met polymorphism affects activity-dependent secretion of BDNF and human memory and hippocampal function. Cell 112, 257-269.

[116] Taylor WD, Züchner S, Mcquoid DR, Payne ME, MacFall J, Steffens D, Speer M, Krishnan KRR (2008) The brainderived neurotrophic factor val66met polymorphism and cerebral white matter hyperintensities in late-life depression. Am J Geriatr Psychiatry 16, 263-271.

[117] Huang CC, Liu ME, Chou KH, Yang AC, Hung CC, Hong CJ, Tsai SJ, Lin CP (2014) Effect of BDNF Val66Met polymorphism on regional white matter hyperintensities and cognitive function in elderly males without dementia. Psychoneuroendocrinology 39, 94-103.

[118] Pezawas L, Verchinski BA, Mattay VS, Callicott JH, Kolachana BS, Straub RE, Egan MF, Meyer-Lindenberg A, Weinberger DR (2004) The brain-derived neurotrophic factor val66met polymorphism and variation in human cortical morphology. J Neurosci 24, 10099-10102.

[119] Bueller JA, Aftab M, Sen S, Gomez-Hassan D, Burmeister M, Zubieta JK (2006) BDNF Val66Met allele is associated with reduced hippocampal volume in healthy subjects. Biol Psychiatry 59, 812-815.

[120] Sanchez MM, Das D, Taylor JL, Noda A, Yesavage JA, Salehi A (2011) BDNF polymorphism predicts the rate 
of decline in skilled task performance and hippocampal volume in healthy individuals. Transl Psychiatry 1, e51.

[121] Nemoto K, Ohnishi T, Mori T, Moriguchi Y, Hashimoto R, Asada T, Kunugi H (2006) The Val66Met polymorphism of the brain-derived neurotrophic factor gene affects agerelated brain morphology. Neurosci Lett 397, 25-29.

[122] Hariri AR, Goldberg TE, Mattay VS, Kolachana BS, Callicott JH, Egan MF, Weinberger DR (2003) Brainderived neurotrophic factor val66met polymorphism affects human memory-related hippocampal activity and predicts memory performance. J Neurosci $\mathbf{2 3}, 6690-6694$.

[123] Miyajima F, Ollier W, Mayes A, Jackson A, Thacker N, Rabbitt P, Pendleton N, Horan M, Payton A (2008) Brainderived neurotrophic factor polymorphism Val66Met influences cognitive abilities in the elderly. Genes Brain Behav 7, 411-417.

[124] Li G, Peskind ER, Millard SP, Chi P, Sokal I, Yu CE, Bekris LM, Raskind MA, Galasko DR, Montine TJ (2009) Cerebrospinal fluid concentration of brain-derived neurotrophic factor and cognitive function in non-demented subjects. PLoS One 4, 1-5.

[125] Pan W, Banks WA, Fasold MB, Bluth J, Kastin AJ (1998) Transport of brain-derived neurotrophic factor across the blood-brain barrier. Neuropharmacology 37, 1553-1561.

[126] Rasmussen P, Brassard P, Adser H, Pedersen MV, Leick L, Hart E, Secher NH, Pedersen BK, Pilegaard H (2009) Evidence for a release of brain-derived neurotrophic factor from the brain during exercise. Exp Physiol 94, 1062-1069.

[127] Fujimura H, Altar CA, Chen R, Nakamura T, Nakahashi T, Kambayashi JI, Sun B, Tandon NN (2002) Brainderived neurotrophic factor is stored in human platelets and released by agonist stimulation. Thromb Haemost $\mathbf{8 7}$, 728-734.

[128] Shimada H, Makizako H, Doi T, Yoshida D, Tsutsumimoto K, Anan Y, Uemura K, Lee S, Park H, Suzuki T (2014) A large, cross-sectional observational study of serum BDNF, cognitive function, and mild cognitive impairment in the elderly. Front Aging Neurosci 6, 1-9.

[129] Knaepen K, Goekint M, Heyman EM, Meeusen R (2010) Neuroplasticity - exercise-induced response of peripheral brain-derived neurotrophic factor: A systematic review of experimental studies in human subjects. Sports Med 40, 765-801.

[130] Huang T, Larsen KT, Ried-Larsen M, Møller NC, Andersen LB (2014) The effects of physical activity and exercise on brain-derived neurotrophic factor in healthy humans: A review. Scand J Med Sci Sports 24, 1-10.

[131] Schwabe L, Joëls M, Roozendaal B, Wolf OT, Oitzl MS (2012) Stress effects on memory: An update and integration. Neurosci Biobehav Rev 36, 1740-1749.

[132] Lupien SJ, Maheu F, Tu M, Fiocco A, Schramek TE (2007) The effects of stress and stress hormones on human cognition: Implications for the field of brain and cognition. Brain Cogn 65, 209-237.

[133] McGaugh JL, Roozendaal B (2002) Role of adrenal stress hormones in forming lasting memories in the brain. Curr Opin Neurobiol 12, 205-210.

[134] Sandi C (2013) Stress and cognition. Wiley Interdiscip Rev Cogn Sci 4, 245-261.

[135] De Kloet ER, Oitzl MS, Joëls M (1999) Stress and cognition: Are corticosteroids good or bad guys? Trends Neurosci 22, 422-426.

[136] McEwen BS, Gianaros PJ (2010) Central role of the brain in stress and adaptation: Links to socioeconomic status, health, and disease. Ann N Y Acad Sci 1186, 190-222.
[137] Miller BR, Hen R (2015) The current state of the neurogenic theory of depression and anxiety. Curr Opin Neurobiol 30, 51-58.

[138] Conrad CD (2008) Chronic stress-induced hippocampal vulnerability: The glucocorticoid vulnerability hypothesis. Rev Neurosci 19, 395-411.

[139] Vermetten E, Vythilingam M, Southwick SM, Charney DS, Bremner JD (2003) Long-term treatment with paroxetine increases verbal declarative memory and hippocampal volume in posttraumatic stress disorder. Biol Psychiatry 54, 693-702.

[140] Hallahan B, Newell J, Soares JC, Brambilla P, Strakowski SM, Fleck DE, Kiesepp T, Altshuler LL, Fornito A, Malhi GS, McIntosh AM, Yurgelun-Todd DA, Labar KS, Sharma V, MacQueen GM, Murray RM, McDonald C (2011) Structural magnetic resonance imaging in bipolar disorder: An international collaborative mega-analysis of individual adult patient data. Biol Psychiatry 69, 326335.

[141] Arnone D, McKie S, Elliott R, Juhasz G, Thomas EJ, Downey D, Williams S, Deakin JFW, Anderson IM (2013) State-dependent changes in hippocampal grey matter in depression. Mol Psychiatry 18, 1265-1272.

[142] Tendolkar I, van Beek M, van Oostrom I, Mulder M, Janzing J, Voshaar RO, van Eijndhoven P (2013) Electroconvulsive therapy increases hippocampal and amygdala volume in therapy refractory depression: A longitudinal pilot study. Psychiatry Res 214, 197-203.

[143] Wheatley D (1997) Stress, anxiety and depression. Stress Med 13, 173-177.

[144] Leuner B, Shors TJ (2013) Stress, anxiety, and dendritic spines: What are the connections? Neuroscience 251, 108119.

[145] Beaudreau SA, O'Hara R (2009) The association of anxiety and depressive symptoms with cognitive performance in community-dwelling older adults. Psychol Aging 24, 507-512.

[146] Potvin O, Hudon C, Dion M, Grenier S, Préville M (2011) Anxiety disorders, depressive episodes and cognitive impairment no dementia in community-dwelling older men and women. Int J Geriatr Psychiatry 26, 1080-1088.

[147] Yochim BP, Mueller AE, Segal DL (2013) Late life anxiety is associated with decreased memory and executive functioning in community dwelling older adults. J Anxiety Disord 27, 567-575.

[148] Butters MA, Bhalla RK, Andreescu C, Wetherell JL, Mantella R, Begley AE, Lenze EJ (2011) Changes in neuropsychological functioning following treatment for late-life generalised anxiety disorder. Br J Psychiatry 199, 211-218.

[149] Peavy GM, Lange KL, Salmon DP, Patterson TL, Goldman S, Gamst AC, Mills PJ, Khandrika S, Galasko D (2007) The effects of prolonged stress and APOE genotype on memory and cortisol in older adults. Biol Psychiatry 62, 472-478.

[150] Kugler J, Seelbach H, Kruskemper GM (1994) Effects of rehabilitation exercise programmes on anxiety and depression in coronary patients: A meta-analysis. $\mathrm{Br} \mathrm{J} \mathrm{Clin}$ Psychol 33, 401-410.

[151] Greenwood BN, Loughridge AB, Sadaoui N, Christianson JP, Fleshner M (2012) The protective effects of voluntary exercise against the behavioral consequences of uncontrollable stress persist despite an increase in anxiety following forced cessation of exercise. Behav Brain Res 233, 314321. 
[152] Petruzzello SJ, Landers DM, Hatfield BD, Kubitz KA, Salazar W (1991) A meta-analysis on the anxiety-reducing effects of acute and chronic exercise: Outcomes and mechanisms. Sport Med 11, 143-182.

[153] Taylor AH (2000) Physical activity, anxiety, and stress. In Physical Activity and Psychological Well-Being, Biddle SJH, Fox KR, Boutcher SH, eds. Routledge, London, pp. $10-45$.

[154] Wipfli BBM, Rethorst CDC, Landers DDM (2008) The anxiolytic effects of exercise: A meta-analysis of randomized trials and dose-response analysis. J Sport Exerc Psychol 30, 392-410.

[155] Anderson E, Shivakumar G (2013) Effects of exercise and physical activity on anxiety. Front Psychiatry 4, 10-13.

[156] Sciolino NR, Holmes PV (2012) Exercise offers anxiolytic potential: A role for stress and brain noradrenergicgalaninergic mechanisms. Neurosci Biobehav Rev 36, 1965-1984.

[157] Schoenfeld TJ, Rada P, Pieruzzini PR, Hsueh B, Gould E (2013) Physical exercise prevents stress-induced activation of granule neurons and enhances local inhibitory mechansims in the dentate gyrus. J Neurosci 33, 77707777.

[158] Herring MP, Lindheimer JB, O'Connor PJ (2014) The effects of exercise training on anxiety. Am J Lifestyle Med 8, 388-403.

[159] Libby P (2002) Inflammation in atherosclerosis. Arterioscler Thromb Vasc Biol 420, 868.

[160] Garcia C, Feve B, Ferré P, Halimi S, Baizri H, Bordier L, Guiu G, Dupuy O, Bauduceau B, Mayaudon H (2010) Diabetes and inflammation: Fundamental aspects and clinical implications. Diabetes Metab 36, 327-338.

[161] Ertek S, Cicero A (2012) Impact of physical activity on inflammation: Effects on cardiovascular disease risk and other inflammatory conditions. Arch Med Sci 8, 794804.

[162] Barrientos RM, Kitt MM, Watkins LR, Maier SF (2015) Neuroinflammation in the normal aging hippocampus. Neuroscience 309, 84-99.

[163] Wilson CJ, Finch CE, Cohen HJ (2002) Cytokines and cognition - The case for a head-to-toe inflammatory paradigm. J Am Geriatr Soc 50, 2041-2056.

[164] Campbell SJ, Hughes PM, Iredale JP, Wilcockson DC, Waters S, Docagne F, Perry VH, Anthony DC (2003) CINC-1 is an acute-phase protein induced by focal brain injury causing leukocyte mobilization and liver injury. FASEB J 17, 1168-1170.

[165] Campbell SJ, Perry VH, Pitossi FJ, Butchart AG, Chertoff M, Waters S, Dempster R, Anthony DC (2005) Central nervous system injury triggers hepatic CC and CXC chemokine expression that is associated with leukocyte mobilization and recruitment to both the central nervous system and the liver. Am J Pathol 166, 1487-1497.

[166] Colton CA (2009) Heterogeneity of microglial activation in the innate immune response in the brain. JNeuroimmune Pharmacol 4, 399-418.

[167] Kreutzberg GW (1996) Microglia: A sensor for pathological events in the CNS. Trends Neurosci 19, 312-318.

[168] Frank MG, Barrientos RM, Watkins LR, Maier SF (2010) Aging sensitizes rapidly isolated hippocampal microglia to LPS ex vivo. J Neuroimmunol 226, 181-184.

[169] Barrientos RM, Thompson VM, Kitt MM, Amat J, Hale MW, Frank MG, Crysdale NY, Stamper CE, Hennessey PA, Watkins LR, Spencer RL, Lowry CA, Maier SF (2015) Greater glucocorticoid receptor activation in hippocampus of aged rats sensitizes microglia. Neurobiol Aging 36, 1483-1495.

[170] Krabbe KS, Pedersen M, Bruunsgaard H (2004) Inflammatory mediators in the elderly. Exp Gerontol 39, 687-699.

[171] Marsland AL, Gianaros PJ, Abramowitch SM, Manuck SB, Hariri AR (2008) Interleukin-6 covaries inversely with hippocampal grey matter volume in middle-aged adults. Biol Psychiatry 64, 484-490.

[172] Monje ML, Toda H, Palmer TD (2003) Inflammatory blockade restores adult hippocampal neurogenesis. Science 302, 1760-1765.

[173] Wieczorek M, Swiergiel AH, Pournajafi-Nazarloo H, Dunn AJ (2005) Physiological and behavioral responses to interleukin-1 $\beta$ and LPS in vagotomized mice. Physiol Behav 85, 500-511.

[174] Cibelli M, Fidalgo AR, Terrando N, Ma D, Monaco C, Feldmann M, Takata M, Lever IJ, Nanchahal J, Fanselow MS, Maze M (2010) Role of interleukin- $1 \beta$ in postoperative cognitive dysfunction. Ann Neurol 68, 360-368.

[175] Schram MT, Euser SM, De Craen AJM, Witteman JC, Frölich M, Hofman A, Jolles J, Breteler MMB, Westendorp RGJ (2007) Systemic markers of inflammation and cognitive decline in old age. J Am Geriatr Soc 55, 708-716.

[176] Yaffe K, Lindquist K, Penninx BW, Simonsick EM, Pahor M, Kritchevsky S, Launer L, Kuller L, Rubin S, Harris T (2003) Inflammatory markers and cognition in well-functioning African-American and white elders. Neurology 61, 76-80.

[177] Weaver JD, Huang M-H, Albert M, Harris T, Rowe JW, Seeman TE (2002) Interleukin-6 and risk of cognitive decline: MacArthur studies of successful aging. Neurology 59, 371-378.

[178] Weuve J, Ridker PM, Cook NR, Buring JE, Grodstein F (2006) High-sensitivity C-reactive protein and cognitive function in older women. Epidemiology 17, 183-189.

[179] Dik MG, Jonker C, Hack CE, Smit JH, Comijs HC, Eikelenboom P (2005) Serum inflammatory proteins and cognitive decline in older persons. Neurology 64, 13711377.

[180] Schmidt R, Schmidt H, Curb JD, Masaki K, White LR, Launer LJ (2002) Early inflammation and dementia: A 25-year follow-up of the Honolulu-Asia Aging Study. Ann Neurol 52, 168-174.

[181] Papassotiropoulos A, Bagali M, Jessen F, Bayer TA, Maier W, Rao M, Heun R (1999) A genetic variation of the inflammatory cytokine interleukin- 6 delays the intial onset and reduces the risk for sporadic Alzheimer's disease. Ann Neurol 45, 666-668.

[182] Schwartz M, Shechter R (2010) Systemic inflammatory cells fight off neurodegenerative disease. Nat Rev Neurol 6, 405-410.

[183] Mathur N, Pedersen BK (2008) Exercise as a mean to control low-grade systemic inflammation. Mediators Inflamm 2008, 1-6.

[184] Woods JA, Wilund KR, Martin SA, Kistler BM (2012) Exercise, inflammation and aging. Aging Dis 3, 130-140.

[185] Taaffe DR, Harris TB, Ferrucci L, Rowe J, Seeman TE (2000) Cross-sectional and prospective relationships of interleukin-6 and C-reactive protein with physical performance in elderly persons: MacArthur studies of successful aging. J Gerontol A Biol Sci Med Sci 55, M709-M715.

[186] Geffken DF, Cushman M, Burke GL, Polak JF, Sakkinen PA, Tracy RP (2001) Association between physical activity and markers of inflammation in a healthy elderly population. Am J Epidemiol 153, 242-250. 
[187] Ford ES (2002) Does exercise reduce inflammation? Physical activity and C-reactive protein among U.S. adults. Epidemiology 13, 561-568.

[188] Elosua R, Bartali B, Ordovas JM, Corsi AM, Lauretani F, Ferrucci L (2005) Association between physical activity, physical performance, and inflammatory biomarkers in an elderly population: The InCHIANTI study. J Gerontol A Biol Sci Med Sci 60A, 760-767.

[189] Borodulin K, Tiina L, Veikko S, Pekka J (2006) Associations of leisure time physical activity, self-rated physical fitness, and estimated aerobic fitness with serum C-reactive protein among 3803 adults. Atherosclerosis 185, 381-387.

[190] Jae SY, Heffernan KS, Lee MK, Fernhall B, Park WH (2008) Relation of cardiorespiratory fitness to inflammatory markers, fibrinolytic factors, and lipoprotein(a) in patients with type 2 diabetes mellitus. Am J Cardiol 102, 700-703.

[191] Olson TP, Dengel DR, Leon AS, Schmitz KH (2007) Changes in inflammatory biomarkers following one-year of moderate resistance training in overweight women. Int J Obes 31, 996-1003.

[192] Stewart LK, Flynn MG, Campbell WW, Craig BA, Robinson JP, Timmerman KL, McFarlin BK, Coen PM, Talbert E (2007) The influence of exercise training on inflammatory cytokines and C-reactive protein. Med Sci Sports Exerc 39, 1714-1719.

[193] Beavers KM, Brinkley TE, Nicklas BJ (2010) Effect of exercise training on chronic inflammation. Clin Chim Acta 411, 785-793.

[194] Fischer CP (2006) Interleukin-6 in acute exercise and training: What is the biological relevance? Exerc Immunol Rev 12, 6-33.

[195] Nimmo MA, Leggate M, Viana JL, King JA (2013) The effect of physical activity on mediators of inflammation. Diabetes Obes Metab 15, 51-60.

[196] Ghasemi R, Haeri A, Dargahi L, Mohamed Z, Ahmadiani A (2013) Insulin in the brain: Sources, localization and functions. Mol Neurobiol 47, 145-171.

[197] Chowers I, Lavy S, Halpern L (1961) Effect of insulin administered intracisternally in dogs on the glucose level of the blood and the cerebrospinal fluid. Exp Neurol 3, 197-205.

[198] Chowers I, Lavy S, Halpern L (1966) Effect of insulin administered intracisternally on the glucose level of the blood and the cerebrospinal fluid in vagotomized dogs. Exp Neurol 14, 383-389.

[199] Wickelgren I (1998) Tracking insulin to the mind. Science 280, 517-520.

[200] Schulingkamp RJ, Pagano TC, Hung D, Raffa RB (2000) Insulin receptors and insulin action in the brain: Review and clinical implications. Neurosci Biobehav Rev 24, 855872.

[201] Zhao W-Q, Chen H, Quon MJ, Alkon DL (2004) Insulin and the insulin receptor in experimental models of learning and memory. Eur J Pharmacol 490, 71-81.

[202] Unger JW, Livingston JN, Moss AM (1991) Insulin receptors in the central nervous system: Localization, signalling mechanisms and functional aspects. Prog Neurobiol 36, 343-362.

[203] Livingstone C, Lyall H, Gould GW (1995) Hypothalamic GLUT 4 expression: A glucose- and insulin-sensing mechanism? Mol Cell Endocrinol 107, 67-70.

[204] El Messari S, Leloup C, Quignon M, Brisorgueil MJ, Penicaud L, Arluison M (1998) Immunocytochemical localization of the insulin-responsive glucose transporter 4 (Glut4) in the rat central nervous system. J Comp Neurol 399, 492-512.

[205] Apelt J, Mehlhorn G, Schliebs R (1999) Insulin-sensitive GLUT4 glucose transporters are colocalized with GLUT3expressing cells and demonstrate a chemically distinct neuron-specific localization in rat brain. $J$ Neurosci Res 57, 693-705.

[206] Ibberson M, Uldry M, Thorens B (2000) GLUTX1, a novel mammalian glucose transporter expressed in the central nervous system and insulin-sensitive tissues. $J$ Biol Chem 275, 4607-4612.

[207] Reagan LP, Gorovits N, Hoskin EK, Alves SE, Katz EB, Grillo CA, Piroli GG, McEwen BS, Charron MJ (2001) Localization and regulation of GLUTx1 glucose transporter in the hippocampus of streptozotocin diabetic rats. Proc Natl Acad Sci U S A 98, 2820-2825.

[208] Adem A, Jossan SS, D’Argy R, Gillberg PG, Nordberg A, Winblad B, Sara V (1989) Insulin-like growth factor 1 (IGF-1) receptors in the human brain: Quantitative autoradiographic localization. Brain Res 503, 299. 303.

[209] Gerozissis K, Kyriaki G (2003) Brain insulin: Regulation, mechanisms of action and functions. Cell Mol Neurobiol 23, 1-25.

[210] Zhao W-Q, Townsend M (2009) Insulin resistance and amyloidogenesis as common molecular foundation for type 2 diabetes and Alzheimer's disease. Biochim Biophys Acta 1792, 482-496.

[211] Zhao W-Q, Alkon DL (2001) Role of insulin and insulin receptor in learning and memory. Mol Cell Endocrinol 177, 125-134.

[212] Fernandez AM, Torres-Alemán I (2012) The many faces of insulin-like peptide signalling in the brain. Nat Rev Neurosci 13, 225-239.

[213] Schubert M, Brazil DP, Burks DJ, Kushner JA, Ye J, Flint CL, Farhang-Fallah J, Dikkes P, Warot XM, Rio C, Corfas G, White MF (2003) Insulin receptor substrate-2 deficiency impairs brain growth and promotes tau phosphorylation. J Neurosci 23, 7084-7092.

[214] Recio-Pinto E, Ishii DN (1984) Effects of insulin, insulinlike growth factor-II and nerve growth factor on neurite outgrowth in cultured human neuroblastoma cells. Brain Res 302, 323-334.

[215] Dickson BJ (2003) Wiring the brain with insulin. Science 300, 440-441.

[216] Song J, Wu L, Chen Z, Kohanski RA, Pick L (2003) Axons guided by insulin receptor in drosophila visual system. Science 300, 502-505.

[217] Yu S-W, Baek S-H, Brennan RT, Bradley CJ, Park SK, Lee YS, Jun EJ, Lookingland KJ, Kim E-K, Lee H, Goudreau JL, Kim SW (2008) Autophagic death of adult hippocampal neural stem cells following insulin withdrawal. Stem Cells 26, 2602-2610.

[218] Plum L, Schubert M, Brüning JC (2005) The role of insulin receptor signaling in the brain. Trends Endocrinol Metab 16, $59-65$

[219] Devaskar SU, Giddings SJ, Rajakumar PA, Carnaghi LR, Menon RK, Zahm DS (1994) Insulin gene expression and insulin synthesis in mammalian neuronal cells. $J$ Biol Chem 269, 8445-8454.

[220] Schechter R, Beju D, Gaffney T, Schaefer F, Whetsell L (1996) Preproinsulin I and II mRNAs and insulin electron microscopic immunoreaction are present within the rat fetal nervous system. Brain Res 736, 16-27. 
[221] Schechter R, Yanovitch T, Abboud M, Johnson G, Gaskins J (1998) Effects of brain endogenous insulin on neurofilament and MAPK in fetal rat neuron cell cultures. Brain Res 808, 270-278.

[222] Park C (2001) Cognitive effects of insulin in the central nervous system. Neurosci Biobehav Rev 25, 311-323.

[223] Banks WA (2004) The source of cerebral insulin. Eur J Pharmacol 490, 5-12.

[224] Akintola AA, van Heemst D (2015) Insulin, aging, and the brain: Mechanisms and implications. Front Endocrinol (Lausanne) 6, 1-13.

[225] Banks WA, Jaspan JB, Huang W, Kastin AJ (1997) Transport of insulin across the blood-brain barrier: Saturability at euglycemic doses of insulin. Peptides 18, 1423-1429.

[226] Banks WA, Jaspan JB, Kastin AJ (1997) Selective, physiological transport of insulin across the blood-brain barrier. Novel demonstration by species-specific radioimmunoassays. Peptides 18, 1257-1262.

[227] Wallum BJ, Taborsky GJ, Porte D, Figlewicz DP, Jacobson L, Beard JC, Ward WK, Dorsa D (1987) Cerebrospinal fluid insulin levels increase during intravenous insulin infusion in man. J Clin Endocrinol Metab 64, 190-194.

[228] Messier C (2004) Glucose improvement of memory: A review. Eur J Pharmacol 490, 33-57.

[229] Reger MA, Watson GS, Frey WH, Baker LD, Cholerton B, Keeling ML, Belongia DA, Fishel MA, Plymate SR, Schellenberg GD, Cherrier MM, Craft S (2006) Effects of intranasal insulin on cognition in memory-impaired older adults: Modulation by APOE genotype. Neurobiol Aging 27, 451-458.

[230] Schwartz MW, Figlewicz DF, Kahn SE, Baskin DG, Greenwood MRC, Porte D (1990) Insulin binding to brain capillaries is reduced in genetically obese, hyperinsulinemic Zucker rats. Peptides 11, 467-472.

[231] Craft S (2005) Insulin resistance syndrome and Alzheimer's disease: Age- and obesity-related effects on memory, amyloid, and inflammation. Neurobiol Aging 26, 65-69.

[232] Tschritter O, Hennige AM, Preissl H, Porubska K, Schäfer SA, Lutzenberger W, Machicao F, Birbaumer N, Fritsche A, Häring HU (2007) Cerebrocortical beta activity in overweight humans responds to insulin detemir. PLoS One 2, $1-7$.

[233] Heni M, Kullmann S, Preissl H, Fritsche A, Häring H-U (2015) Impaired insulin action in the human brain: Causes and metabolic consequences. Nat Rev Endocrinol 11, 701711.

[234] Wang Y, Perfetti R, Greig NH, Holloway HW, DeOre KA, Montrose-Rafizadeh C, Elahi D, Egan JM (1997) Glucagon-like peptide-1 can reverse the age-related decline in glucose tolerance in rats. J Clin Invest 99, 28832889

[235] Gerozissis K, Rouch C, Lemierre S, Nicolaidis S, Orosco M (2001) A potential role of central insulin in learning and memory related to feeding. Cell Mol Neurobiol 21, $389-401$.
[236] Kanaya AM, Barrett-Connor E, Gildengorin G, Yaffe K (2004) Change in cognitive function by glucose tolerance status in older adults. Arch Intern Med 164, 1327-1333.

[237] Logroscino G, Kang JH, Grodstein F (2004) Prospective study of type 2 diabetes and cognitive decline in women aged 70-81 years. BMJ 328, 548.

[238] Strachan MWJ, Reynolds RM, Marioni RE, Price JF (2011) Cognitive function, dementia and type 2 diabetes mellitus in the elderly. Nat Rev Endocrinol 7, 108-114.

[239] Convit A, Wolf OT, Tarshish C, de Leon MJ (2003) Reduced glucose tolerance is associated with poor memory performance and hippocampal atrophy among normal elderly. Proc Natl Acad Sci U S A 100, 2019-2022.

[240] Messier C, Tsiakas M, Gagnon M, Desrochers A, Awad N (2003) Effect of age and glucoregulation on cognitive performance. Neurobiol Aging 24, 985-1003.

[241] Correia SC, Santos RX, Carvalho C, Cardoso S, Candeias E, Santos MS, Oliveira CR, Moreira PI (2012) Insulin signaling, glucose metabolism and mitochondria: Major players in Alzheimer's disease and diabetes interrelation. Brain Res 1441, 64-78.

[242] Claxton A, Baker LD, Hanson A, Trittschuh EH, Cholerton B, Morgan A, Callaghan M, Arbuckle M, Behl C, Craft $S$ (2015) Long-acting intranasal insulin detemir improves cognition for adults with mild cognitive impairment or early-stage Alzheimer's disease dementia. J Alzheimers Dis 44, 897-906.

[243] Seals DR, Hagberg JM, Allen WK, Hurley BF, Dalsky GP, Ehsani AA, Holloszy JO (1984) Glucose tolerance in young and older athletes and sedentary men. $J$ Appl Physiol 56, 1521-1525.

[244] Jensen CS, Hasselbalch SG, Waldemar G, Simonsen AH (2015) Biochemical markers of physical exercise on mild cognitive impairment and dementia: Systematic review and perspectives. Front Neurol 6, 1-10.

[245] Baker LD, Frank LL, Foster-Schubert K, Green PS, Wilkinson CW, McTiernan A, Plymate SR, Fishel MA, Watson GS, Cholerton BA, Duncan GE, Mehta PD, Craft $S$ (2010) Effects of aerobic exercise on mild cognitive impairment: A controlled trial. Arch Neurol 67, 71-79.

[246] Cheng S-T, Chow PK, Song Y-Q, Yu ECS, Chan ACM, Lee TMC, Lam JHM (2014) Mental and physical activities delay cognitive decline in older persons with dementia. $A m$ J Geriatr Psychiatry 22, 63-74.

[247] Borghouts LB, Keizer HA (2000) Exercise and insulin sensitivity: A review. Int J Sports Med 21, 1-12.

[248] Mann S, Beedie C, Balducci S, Zanuso S, Allgrove J, Bertiato F, Jimenez A (2014) Changes in insulin sensitivity in response to different modalities of exercise: A review of the evidence. Diabetes Metab Res Rev 30, 257-268.

[249] McEwen BS (2000) Allostasis and allostatic load: Implications for neuropsychopharmacology. Neuropharmacology 22, 108-124.

[250] Marosi K, Mattson MP (2014) BDNF mediates adaptive brain and body responses to energetic challenges. Trends Endocrinol Metab 25, 89-98. 